\title{
Implementation of the CTL Model with the CEP Approach to Improve Student Learning Outcomes and Entrepreneurial Interest in Matter-Properties and Changes in Vocational School
}

\author{
Muhammad Zia Ulhaq ${ }^{1 凶}$, Nanik Wijayati ${ }^{2}$, Woro Sumarni ${ }^{2}$ \\ ${ }^{1}$ El Hijrah STIKes YPIB II Cirebon, Indonesia \\ ${ }^{2}$ Pascasarjana, Universitas Negeri Semarang, Indonesia
}

\begin{tabular}{l}
\hline Article Info \\
\hline Article History : \\
Received March 2020 \\
Accepted April 2020 \\
Published April 2021 \\
\hline Keywords: \\
CTL Learning, CEP \\
Learning, Entrepreneurial \\
Interest \\
\hline
\end{tabular}

\begin{abstract}
The results of studying and entrepreneurial interest of students of SMK (Vocational School) Nusantara in Cirebon are still low. The learning strategies were used by teachers are generally conventional and not optimal for improving the learning outcomes and entrepreneurial interest of the student in schools. The type of research method used in this research is an experiment. The research data analysis technique used is the independent sample t-test. The result of this study is (1) the value of Sig. (2-tailed) obtained at $0.004<0.05$ means there is an influence on the use of the CTL learning model with the CEP approach to improving student learning outcomes. (2) The test value of the Independent sample t-test sig. (2-tailed) amounting to $0.000<0.05$ which means that there is an average difference in student learning outcomes between the experimental groups and the control, in other words, the application of the CTL model with the CEP approach with other learning methods will result in indifferent learning. (3) the test result of $\mathrm{N}$ gain experimental class $58.03 \%$ (quite effective) while control group $34.38 \%$ (less effective) the results of this research are expected to be one of the solutions for educational practitioners, especially in vocational schools to equip students with entrepreneurial skills to reduce the impact of unemployment.
\end{abstract}

$\square$ correspondence :

E1 Hijrah STIKes YPIB II Cirebon 


\section{INTRODUCTION}

Indonesia's total labor force is 128.06 million. In August 2016 the number has increased by 2.62 million people. This is consistent with the labor force participation rate, which increased 0.33 points. In the last year, unemployment increased to 10 thousand people, while the TPT dropped by 0.11 points. Judging from the education level, TPT for vocational School (SMK) is the highest among other education levels, which is 11.41 percent. (Central Statistic Agency, 2017).

One of the state's efforts in the fulfillment of high-level human resources is the vocational education training. The meaning of vocational education is very varied. According to law explanation number 20 the year 2003 article 15, vocational education is a secondary education that prepares students primarily to work in a particular field. Vocational education consists of vocational high school, and vocational Madrasah Aliyah.

Learning is not merely mastering a set of knowledge that is fact, concept, principle or theory, but learning will be more meaningful if learners experience what they are learning; Schools in order to be used in their daily lives (Zubaedi, 2011)

Based on the results of interviews with two chemical teachers from SMK Nusantara Weru in Cirebon, shows that teachers still use conventional learning such as lectures, questions and answers, and exercises. Rudhumbu (2014) in his research in one of the developing countries found the fact that the strategy that the teacher used was still teachingcentered instead of student-centered.

Chemistry as a process and product should be able to contribute significantly in improving the intelligence of students. By studying chemistry, various symptoms or natural phenomena can be known. In addition, chemistry can also be used as a tool to educate people (students) in order to have knowledge, skills, and scientific attitudes (Karyadi, 2005). If learners are accustomed to such learning conditions, not closing will likely motivate them for entrepreneurship (Supartono, 2012).

One of the learning models that can facilitate students to more meaningful learning is using the CTL model, a learning that begins with an oral dish or Q \&amp; A (friendly, open, negotiation) that is related to real-life Students (daily life modeling), so it will really feel the benefits of the material presented. (Ngalimun, 2012).

The Contextual Teaching and learning Learning Model expands the student's personal context further through the provision of a fresh experience that stimulates the brain to establish new relationships to discover new meaning) (Rusman, 2011).

According to Syaiful Sagala, (2012) mentions seven major components of contextual learning, namely: (a) constructivism; (b) Find; (c) Inquire; (d) Learning society; (e) modeling; (f) Reflection; (g) Actual assessment. The concept of the CTL model with the CEP approach in chemical learning is very suitable applied. The CTL Model Associates learning with real-life or every day, while the CEP approach of students can learn the process of processing an ingredient into a beneficial product, economic value and foster an entrepreneurial spirit so that The use of the CTL model with the CEP approach to the chemical subjects will be more enjoyable and provide students with the opportunity to optimize their potential to produce a product (Teguh et al., 2018).

Learning with the CEP approach is expected to foster a passion/entrepreneurial spirit for students in the teaching and learning process. According to Sumarni (2009), One's passion/entrepreneurial spirit is reflected in various things such as ability, independence (including persistence, teamwork, creativity, and innovation).

According to Susilogati (2008), A model of basic chemistry-oriented laboratory learning can be utilized by students in all high, moderate and lowperformance groups to improve the entrepreneurial spirit. Through an example of learning that has been applied, it is recommended for students to provide a direct experience of learning that does not merely provide knowledge but to provide the development of entrepreneurial spirit for Subjects that learn.

Therefore the CTL model with the CEP approach makes the chemistry lesson more attractive, enjoyable and more meaningful. The implementation of the CTL model with the CEP approach is expected to provide solutions to the learning outcomes and entrepreneurial interests of students. 


\section{METHOD}

The research method used is experimentation. In experimental classes and the control, the group is observed at each meeting and in the deployment poll the students ' entrepreneurial interest at the last meeting. An experimental group is a group that is given character-integrated contextual learning, while the control group is a class given conventional learning.

The population of this research is grade $\mathrm{X}$ students at SMK Nusantara Weru Cirebon 1st semester 2019/2020. The sampling technique used is a random sampling cluster, i.e. the retrieval of sample members in the population is carried out randomly based on the class with the requirements of the population distributing a normal distribution and having the same homogeneity (Arikunto, 2006).

The data collection techniques used in this study are tests, polls, and observations. The research instruments used in this research are test sheets (pre-test and post-test), affective observation sheets, psychomotor and entrepreneurial interest.

Data analysis techniques conducted include, (1) The processing of the results of the validation of observation sheets and polls of entrepreneurial interests of students, (2) The processing of observation results and questionnaire for entrepreneurial interest students, and (3) the test of the improvement of student learning outcomes Use independent sample t-test and paired t-test sample.

(4) Entrepreneurship product manufacture (dish soap)

\section{RESULTS AND DISCUSSION}

In this research, efforts to improve learning outcomes and entrepreneurial interest of students were conducted by (1) using the CTL learning model with the CEP approach, (2) delivering the product manufacture skills of dish soap, (3) providing motivation and Entrepreneurial skills by marketing products or created work.

The average value of learning outcomes gained for the control group is 63.33, while the experimental group is 72.33. Experiment grade students ' learning values are higher than the control group. The average test is used to see the comparison between the values of the student learning outcomes of the control group and the experimental group. The average experimental group learning results have increased from 34.33 to 72.33 .

This is in line with the research of Firdaus et al (2018) in his research stating The results can improve The students' achievement of competencies and give direct experience to students to conduct The research. This is evidenced by the increase of the average mark from 63.78 to 78.91 and the availability of students to write good research reports.

Increasing measurement of student learning results can be done through pre-test and post-test results. Pre-test and post-test results are tested in advance for normal distribution or not by using the Shapiro Wilk test on IBM SPSS Statistic 21 application. The use of the Shapiro Wilk test is because the sample is not exceeding 50 samples ( 30 samples). Data tested with normal and homogeneous distribution so that the next test can be done, namely the parametric test. Parametric test Using Test Paired sample t-test and independent sample t-test.

This study used a test paired sample t-test. Test paired sample t-test is part of a comparative hypothesis test or comparative test. This t-test sample paired test aims to determine if there are any average differences (two groups) that are paired or related and know the presence or absence of a CTL learning influence with the CEP approach. Formula hypothesis Research:

$\mathrm{H}_{0}$ : There is no average difference between the results of a pre-test study with a post-test which means there is no influence on the use of the CTL model with the CEP approach to improving student learning outcomes of grade $\mathrm{X}$ TKR SMK Nusantara Weru Cirebon.

Ha: There is an average difference between the results of study pre-test with post-test which means that there is the influence of the use of CTL model with the CEP approach in improving the learning outcomes of class X TKR SMK Nusantara Weru Cirebon

According to Singgih Santoso (2014:265), the guidelines for decision-making in the test paired sample t-test based on the value of significance (Sig.) Results/output SPSS is as follows:

1. If the value of SIG. (2-tailed) $<0.05$, then $\mathrm{H}_{0}$ rejected and $\mathrm{Ha}$ received 
2. Conversely, if the value of SIG, (2-tailed) $>0.05$, then $\mathrm{H} 0$ accepted and $\mathrm{Ha}$ rejected.

Based on test paired sample t-test of SIG. (2tailed) obtained at $0.004<0.05$ It can be concluded there is a significant difference between the average student learning outcomes in the group of experiments and the control group which means there is an influence on the use of the CTL learning model with the CEP approach to improving student learning outcomes.

In addition to comparing significance values (2-tailed) with probability 0.05 , there are other ways that can be done for hypothesis testing in this paired t-test sample test. That is by the comparison between the value of the calculated $\mathrm{T}$ with the $\mathrm{T}$ table. The guidelines or basic decision-making are as follows:

1. If the value of $\mathrm{T}_{\text {count }}>\mathrm{T}$ table, then $\mathrm{H}_{0}$ rejected and $\mathrm{Ha}$ received

2. Conversely, if $\mathrm{T}_{\text {count }}<\mathrm{t}$ table, then $\mathrm{H}_{0}$ is accepted and $\mathrm{Ha}$ is rejected.

Based on test $\mathrm{T}$ (Paired Sample t-test) is known to calculate the negative value of-20,532. $\mathrm{T}$ calculate the negative value caused due to the average value of learning results pre-test is lower than the average results of the post-test study. In the context of a case like this then the negative counting $\mathrm{T}$ value can be positive. So the calculated $\mathrm{T}$ value becomes 20,532.

Next is the stage of finding the t-table, where the t-table is based on DF value (degree of freedom or degrees of freedom) and significance value (A/2). From the test results, the value of DF is 29 and the value of $0.05 / 2$ equals 0.025 . This value is used as a reference base in the search for t-table on a statistical table $\mathrm{T}$ value distribution. Then meet $\mathrm{T}$ value of the table is 2,045 .

Thus, as the value of $\mathrm{T}_{\text {count }} 20,532>\mathrm{T}$ table 2,045 then as the basis of decision making can be concluded that $\mathrm{H}_{0}$ rejected and $\mathrm{Ha}$ accepted. So it can be concluded there is an average difference of pre-test learning results with a post-test which means there is an influence of the implementation of the CTL learning model with the CEP approach in improving student learning outcomes.

The results of the research by Nurrohmah (2012) show that the use of Contextual Teaching and Learning (CTL) has a positive impact on increasing the learning interest of students. Conscience (2014) states that contextual learning is quite significant for student learning outcomes. In addition, contextual learning can improve the motivation and creativity of students.

According to the results of the Tegar Study (2015) was obtained the average class pretests experiment was 37.24 and the control group 35.03 while the final value of class for is 83.25 and the control group 80.75 . The effect of free variables on control variables amounted to 0.517 categorized as moderate. The increased chemo-entrepreneurship capability of the experimental group was $57 \%$ while the control group was $54 \%$. The end-value test results in the ability of the experiment group chemoentrepreneurship better than the control group.

The independent test sample t-test is a statistical analysis aimed at comparing two samples that do not pair each other. The independent test sample t-test is part of the parametric inferential statistic. It should be understood that in parametric statistic there are conditions that must be met prior to conducting hypotheses as to the assumption of the terms of Use test Independent sample t-test as follows

1. Both samples are not paired together

2. Amount of data for each sample no more than 30 pieces (Singgih Santoso, 2014:270)

3. The data used in this test is of quantitative data (original data)

4. Data of both samples with normal distribution

5. The similarity of variance or homogeneous

To find out if there is a difference in the average student learning outcomes in the experiment group and the control group, it is necessary to create a hypothesis (alleged) formula as follows:

$\mathrm{H}_{0}$ : No average student learning outcomes in experimental groups with control groups

Ha: The average difference in student learning results in an experimental group with a control group

Before interpreting the test result independent sample t-test then first know the basis of decision making as follows:

1. If the value of Sig. (2-tailed) $>0.05$ then $\mathrm{H}_{0}$ received and Ha rejected, which means there is no average difference of student learning results between the experiment group and the control group

2. If the value of Sig. (2-tailed) $<0.05$ then $\mathrm{H}_{0}$ rejected and Ha accepted, which means there is 
an average difference of student learning results between the experiment group and the control group

Based on the independent test sample t-test known sig. (2-tailed) for $0.000<0.05$, as the basis of decision making in Test independent sample t-test, can be deduced $\mathrm{H}_{0}$ rejected and $\mathrm{Ha}$ received. It can, therefore, be concluded that there is a significant (real) difference between the average student learning outcomes in the experiment group with the controls.

The decision-making based on the calculated t-count value with the t-table in this independent sample t-test can be guided by the following decision policy:

1. If t-count the $<\mathrm{t}$-table then the $\mathrm{HO}$ is received and $\mathrm{Ha}$ is rejected, which means there is no average difference of student learning results of the experiment group with the control

2. If t-count $>\mathrm{t}$-table then $\mathrm{H}_{0}$ rejected and $\mathrm{Ha}$ accepted, which means there is an average difference of student learning results of the experiment group with the control

Known calculated t-value of 3,892 > t-table 2,021 , by comparison of the calculated t-value with t-table can be deduced $\mathrm{H}_{0}$ rejected and $\mathrm{Ha}$ accepted, which means there is an average difference of student learning results between experiment groups with control by In other words the application of the CTL model with the CEP approach with other learning methods will result in different learning.

The average value of $\mathrm{N}$-gain score for the experimental group (the CTL model with the CEP approach) is 58,033 or $58.03 \%$ including the category quite effective with the value of $\mathrm{N}$-gain score of at least $33.33 \%$ and maximum of $90.91 \%$, while for the average $\mathrm{N}$-gain score for The control group (conventional method) is 34,383 or $34.38 \%$ including the less effective category with a value of $\mathrm{N}$-gain score of at least- $11.11 \%$ and a maximum of $69.23 \%$. Thereby it can be concluded that the use of the CTL model with the CEP approach is effective enough to improve student learning outcomes.

This is in line with the study of Annisa et al (2017) stating that the outcome of the chemistry study of Grade XI students from SMA Negeri I Sunggal TA 2014/2015 taught by CTL Model based on study lesson with Mind Mapping Media is higher (72.88 per\%) than is taught by $\mathrm{L}$
Conventional income model (68.97\%) In the colloid point system

In addition to the cognitive instruments (pretest and post-test), researchers also use the instruments of affective and psychomotor aspects. Based on Figure 1, the effective analysis shows the fifth aspect of the experimental class, which is a 4aspect, two-to-3.53 aspect, the third aspect of 3.14, the four-3.25 aspect and the fifth aspect of 3.14 .

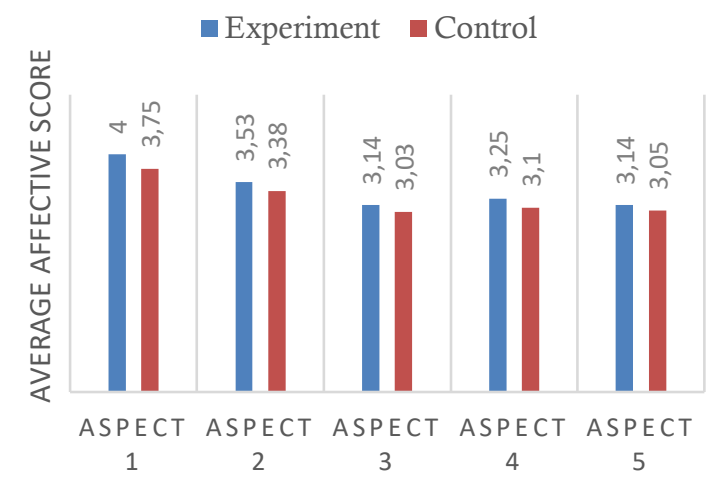

Figure 1. Student's affective Assessment results

The average value of the effective assessment, from the five aspects assessed by the experiment group, is superior to the control group. This means the application of the CTL model with the chemoentrepreneurship approach not only affects the outcome of cognitive learning only but on the affective aspect as well. The average on experimental groups reached 85.31 and the control group was 81.41 .

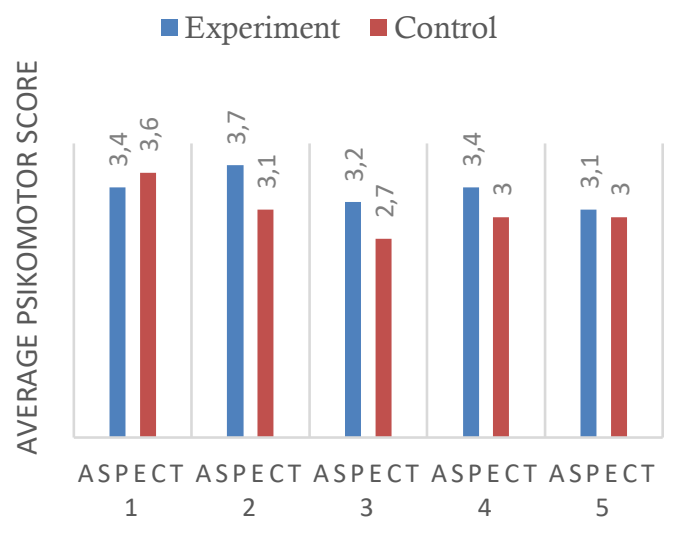

Figure 2. Psychomotor assessment results of students

Based on the general Analysis the experiment group showed better than the control group. The student average in the experiment group reached $83.5 \%$ and the control group was $77.3 \%$. The 
experimental group showed a good learning process.

Based on the results of poll processing it is known that in general, the interest of entrepreneurial students belongs to a high category, which means the CEP approach on learning material change and mixture separation has a positive effect on the students ' entrepreneurial interests. The results of a percentage of 16 questions and 4 indicators show the outcome of most entrepreneurial interest, one of the indicators shows almost entirely and entirely. It is in line with Sunarya. R.A. et al., (2018) stated that from 38 students there are 10 students who have an entrepreneurial interest with high criteria with a percentage of $26.32 \%$ and 28 students have a very high entrepreneurial interest with a percentage of $73.68 \%$. These results suggest that CEP-oriented learning has a positive impact on growing the interest of student entrepreneurship.

\section{CONCLUSION}

Based on results and discussions, this research has a conclusion (1) application of the CTL model with them entrepreneurship approach to material change material and mix separation based on test $\mathrm{T}$ (paired sample t-test) two groups in pairs of GIS values. (2-tailed) acquired $0.004<0.05$ it can be concluded there is a significant difference between the average student learning outcomes in the experimental group and the control group which means there is an influence on the use of the CTL learning model with the CEP approach to Improve student learning outcomes. Comparing the value of the calculated $\mathrm{T} 20,532>\mathrm{T}_{\text {table }} 2,045$ so that it can be concluded there is an average difference of pretest learning results with a post-test which means there is an influence of implementation of the CTL learning model with the CEP approach in improving student learning outcomes. (2) based on test $\mathrm{T}$ (Independent sample t-test) the value of SIG. (2-tailed) for $0.000<0.05$, it can be concluded that there is a significant (real) difference between the average student learning results in the experiment group with the control. (3) based on average $\mathrm{N}$ Gain score group experiment (the CTL model with the CEP approach) is 58,033 or $58.03 \%$ including the category is quite effective with the value of $\mathrm{N}$ gain score at least $33.33 \%$ and maximum of
90.91\%, while for the average $\mathrm{N}$-gain score group the control (conventional method) is 34,383 or $34.38 \%$ including the category less effective with a value $\mathrm{N}$-gain score of at least-11.11\% and a maximum of $69.23 \%$. Thereby it can be concluded that the use of the CTL model with the CEP approach is effective enough to improve student learning outcomes. (4) Based on the analysis of the average affective value in the experimental group $85.31>$ control group 81.41 while for Psychomotor value indicates the experiment group is better than the control group. The student average in the experiment group reached $83.5 \%$ and the control group was $77.3 \% .5$

Based on the results of poll processing it is known that in general, the interest of entrepreneurial students belongs to a high category, which means the CEP approach on learning material change and mixture separation has a positive effect on the students ' entrepreneurial interests. It is in line with Sunarya. R.A. et al., (2018) stated that from 38 students there are 10 students who have an entrepreneurial interest with high criteria with a percentage of $26.32 \%$ and 28 students have a very high entrepreneurial interest with a percentage of $73.68 \%$. These results suggest that CEP-oriented learning has a positive impact on growing the interest of student entrepreneurship. An entrepreneurial interest poll contains thirteen statements covering eight entrepreneurial indicators.

Table 1. Percent of entrepreneurial interest

\begin{tabular}{lll}
\hline $\begin{array}{l}\text { Question } \\
\text { Number }\end{array}$ & Percent of Polls (\%) & Description \\
\hline 1 & 78.33 & Most \\
2 & 67.5 & Most \\
3 & 70.83 & Most \\
4 & 67.5 & Most \\
5 & 68.33 & Most \\
6 & 58.33 & Most \\
7 & 59.16 & Most \\
8 & 77.5 & Most \\
9 & 77.5 & Most \\
10 & 100 & Entirely \\
11 & 75 & Most \\
12 & 75 & Most \\
13 & 75 & Most \\
14 & 53.33 & Most \\
15 & 70.83 & Most \\
16 & 87.5 & Completely \\
\hline
\end{tabular}




\section{REFERENCES}

Arikunto, Suharsimi. 2002. Prosedur Penelitian Suatu Pendekatan Praktek. Jakarta: Rineka Cipta.

Badan Pusat Statistik, (2017) https://www.bps.go.id/pressrelease/2017/11/06 /1377/agustus-2017--tingkat-pengangguranterbuka--tpt--sebesar-5-50-persen.html (diunduh 6 januari 2018)

Clarke, D. \& Roche, A. (2017). Using Contextualized Tasks to Engage Students in Meaningful and Worthwhile Mathematics Learning. Journal of Mathematical Behavior, 51, 95-100.

Fadillah, A., Dewi, N.,I.,P.,L.,C., Nurkholis, A.M., (20016) The Effect of Application of Contextual Teaching and Learning (CTL) Model-Based On Lesson Study With Mind Mapping Media To Assess Student Learning Outcome On Chemistry On Colloid Systems

Firdaus, Dewi, F. (2018) Application of Contextual Teaching and Learning (CTL) Components In Telecommunication Network Design and Optimization Course. International Journal of Chemistry Education Research, Vol 2

Hayati, M. N., Supardi, K. I., \& Miswadi, S. S. (2013). Pengembangan Pembelajaran IPA SMK dengan Model Kontekstual Berbasis Proyek Untuk Meningkatkan Hasil Belajar dan Keterampilan Proses Sains Siswa. Jurnal Pendidikan IPA Indonesia, 2(1), 53-58.

Johnson, E. B. (2007). Contextual Teaching and Learning: Menjadikan Kegiatan Belajar Mengajar Mengasyikkan dan Bermakna. Diterjemahkan oleh Ibnu Setiawan. Bandung: Mizan Learning Center.

Karyadi, Benny. 2005. Pendidikan imia dalam Mewujudkan Pertumbuhan Industri yang Ramah Lingkungan dan Hemat Energi, Makalah Seminar Nasional Kimia dan Pendidikan Kimia. Jurusan Kimia FMIPA UNNES. Semarang.

Ngalimun. 2012. Strategi dan Model Pembelajaran. Banjarmasin: Aswaja Pressindo

Nurani, D. (2014). Pengaruh Penggunaan Pembelajaran Contextual Teaching and Learning terhadap Keterampilan Berpikir Kreatif Siswa pada Pembelajaran Biologi Kelas X SMA N 1 Bangunrejo Tahun Pelajaran 2013/2014. Jurnal Pendidikan Biologi Bioedukasi, 5(2), 79-86.

Nurrohmah, K. (2012). Penerapan Contextual Teaching And Learning (CTL) untuk Meningkatkan Hasil Belajar Biologi Konsep Saling Ketergantungan dalam Ekosistem. Jurnal Ilmu-ilmu Sosial dan Humaniora, 8(2), 139-148.

Rahardiana, G. (2015). Pengaruh Pembelajaran Contextual Teaching And Learning (CTL) Dilengkapi Lab Riil Dan Virtuil Terhadap Aktivitas dan Prestasi Belajar Siswa pada Materi
Pokok Sistem Koloid Kelas XI IPA Semester Genap SMA Negeri 1 Pulokulon Tahun Pelajaran 2013/2014. Jurnal Pendidikan Kimia, 4(1), 120-126.

Rohmah, K. K. \& Marimin. (2015). Pengaruh Persepsi Siswa Mengenai Keterampilan Mengajar, Kompetensi Kepribadian, dan Kompetensi Sosial Guru, terhadap Prestasi Belajar Siswa Program Studi Administrasi Perkantoran Di SMK Negeri 1 Purwodadi. Jurnal Pendidikan Ekonomi Dinamika Pendidikan, 10(1), 28-41.

Rudhumbu, N. (2014). The Use of Motivational Teaching Methods in Primary Schools Mathematics in Zimbabwe: A Case Of The First Decade After Independence. British Journal of Education, 2(3), 22-36.

Rusman. 2011. Model-Model Pembelajaran, Mengembangkan Profesionalisme Guru. Jakarta : Rajawali Pers

Sagala, Syaiful. 2006. Konsep dan makna Pembelajaran. Bandung: Alfabeta.

Sagala, Syaiful. 2010. Supervisi Pembelajaran dalam Profesi Pendidikan. Bandung: Alfabeta.

Sanjayanti, N. P. A. H., Sadia, I. W., \& Pujani, N. M. (2013). Pengaruh Model Contextual Teaching and Learning Bermuatan Pendidikan Karakter terhadap Keterampilan Berpikir Kreatif dan Sikap Ilmiah Ditinjau dari Motivasi Belajar. E-Journal Program Pascasarjaana Universitas Pendidikan Ganesha, 3, 1-11.

Santoso, Singgih. 2014. Statistik Multivariat Edisi Revisi. Jakarta: PT Elex Media Komputindo.

Sari, T. D., Masril, \& Gusnedi. (2014). Pengaruh Penerapan LKS Bermuatan Nilai-Nilai Karakter Dalam Strategi Pembelajaran Contextual Teaching And Learning (CTL) terhadap Hasil Belajar Fisika Siswa Kelas XI IPA SMAN 1 Koto XI Tarusan. Pillar Of Physics Education, 3, 145-152.

Sukidjo, Muhson, A., Mustofa, \& Sholeh, M. (2013). Pengembangan Character Building dengan Contextual Teaching and Learning dalam Pembelajaran Perpajakan di Jurusan Pendidikan Ekonomi Fakultas Ekonomi Universitas Negeri Yogyakarta. Jurnal Pendidikan, 22(1), 1-13.

Sumarni, W., 2009, Peningkatan Efektivitas Perkuliahan Kimia Dasar Melalui Pembelajaran Berorientasi Chemo- Entrepreneurship (CEP) Menggunakan Media Chemo-Edutainment (CET), Lembaran Ilmu Kependidikan, Vol 40, No 1, Hal: 53-58.

Supartono, 2012, Implementasi Soft Skill dalam Pembelajaran Chemoentrepreneurship (CEP) sebagai Upaya Pengembangan Konservasi Sumber Daya Insani, Prosiding Seminar Nasional Kimia dan Pendidikan Kimia Jurusan Kimia FMIPA UNNES, Semarang 16 Oktober 2012.

Undang-Undang Republik Indonesia Nomor 20 Tahun 2003 Tentang Sistem Pendidikan Nasional 
Wibowo, Teguh, \& Ariyatun (2018). Penerapan Pembelajaran Chemoentrepreneurship kreativitas siswa SMA Modern Pondok Selama pada Materi Kelarutan dan $\mathrm{K}_{\mathrm{sp}}$. Jurnal Tadris Kimiya, (3), 62-72
Widodo, G. S., Hariyono, \& Hanurawan, F. (2016). Persepsi Guru tentang Kenakalan Siswa: Studi Kasus di Sekolah Dasar "Raja Agung". Jurnal Pendidikan dan Pembelajaran, 23(2), 142-155.

Zubaedi. (2011). Desain pendidikan karakter konsepsi dan aplikasinya dalam lembaga pendidikan. Jakarta: Kencana prenada media group 